\title{
Kausalitas Pertumbuhan Ekonomi Daerah, Suku Bunga, dan Permintaan-Penawaran Kredit: Pemodelan Simultan
}

\section{Causality of Regional Economic Growth, Interest Rate, and Credit Demand-Supply: Simultaneous Modeling}

\author{
Suriani Suriani $^{1)}$, Chenny Seftarita ${ }^{2)}$ \\ ${ }^{1,2)}$ Fakultas Ekonomi dan Bisnis, Universitas Syiah Kuala, Kota Banda Aceh \\ e-mail korespondensi:suriani@unsyiah.ac.id
}

\begin{tabular}{|l|}
\hline Info Artikel \\
\hline Riwayat Artikel : \\
Diterima: 01 Agustus 2021 \\
Disetujui: 08 September 2021 \\
Dipublikasikan: Januari 2022 \\
\hline Nomor DOI \\
10.33059/jseb.v13i1.3962 \\
Cara Mensitasi : \\
Suriani, S., \& Seftarita, C. \\
(2022). Kausalitas pertumbuhan \\
ekonomi daerah, suku bunga, \\
dan permintaan-penawaran \\
kredit: Pemodelan simultan. \\
Jurnal Samudra Ekonomi dan \\
Bisnis, 13(1), 61-75. doi: \\
10.33059/jseb.v13i1.3962.
\end{tabular}

10.33059/jseb.v13i1.3962.

\begin{abstract}
Abstrak
Penelitian ini bertujuan untuk menganalisis pengaruh pertumbuhan ekonomi daerah dan tingkat suku bunga terhadap permintaan-penawaran kredit di provinsi aceh. Tujuan awal regresi reduksi untuk menganalisis pengaruh loan to deposit ratios, non-performing loans, loan to value, dan suku bunga terhadap pertumbuhan ekonomi daerah dan tahapan akhir untuk menyelidiki hubungan kausal antara pertumbuhan ekonomi daerah dan total kredit yang disalurkan di Provinsi Aceh. Periode data yang digunakan adalah tahun 2011-2014 dalam kuartalan. Metode yang digunakan adalah regresi two-stage least square. Hasil regresi menunjukkan bahwa pertumbuhan ekonomi daerah berpengaruh positif terhadap jumlah penyaluran kredit perbankan. Namun, suku bunga tidak mempengaruhi total penyaluran kredit. Hasil uji kausalitas menjelaskan bahwa pertumbuhan ekonomi daerah memiliki hubungan kausalitas dengan jumlah penyaluran kredit. Pemerintah daerah dapat meningkatkan perekonomian daerah dengan mendukung penyaluran pendanaan ekonomi produktif melalui lembaga keuangan perbankan.
\end{abstract}

Kata Kunci: Kausalitas, Pertumbuhan Ekonomi Daerah, Permintaan-Penawaran Kredit, Simultan.

\begin{tabular}{|l|}
\hline Article Info \\
\hline Article History: \\
Received: 01 August 2021 \\
Accepted: 08 September 2021 \\
Published: January 2022 \\
\hline DOI Number : \\
10.33059/jseb.v13i1.3962 \\
How to cite: \\
Suriani, S., \& Seftarita, C. \\
(2022). Kausalitas pertumbuhan \\
ekonomi daerah, suku bunga, \\
dan permintaan-penawaran \\
kredit: Pemodelan simultan. \\
Jurnal Samudra Ekonomi dan \\
Bisnis, 13(1), 61-75. doi: \\
10.33059/jseb.v13i1.3962.
\end{tabular}

\begin{abstract}
This study analyzes the effect of regional economic growth and interest rates on the demand-supply of credit in Aceh Province. The initial objective of the reduction regression is to analyze the effect of loan to deposit ratios, nonperforming loans, loan to value, and interest rates on regional economic growth and the final stage is to investigate the causal relationship between regional economic growth and total loans disbursed in Aceh Province. The data period used is 2011-2014 quarterly. The method used was two-stage least square regression. The regression results indicate that regional economic growth has a positive effect on bank lending. However, interest rates do not affect total lending. The results of the causality test explain that regional economic growth has a causal relationship with credit disbursement. The local governments can improve the regional economy by supporting productive economic funding through banking financial institutions.
\end{abstract}

Keywords: Causality, Regional Economic Growth, Credit Demand-Supply, Simultaneous. 


\section{PENDAHULUAN}

Perekonomian makro yang kondusif dan kestabilan harga menjadi satu pertimbangan penting bagi setiap pelaku kegiatan ekonomi. Faktor makroekonomi mempengaruhi proses pembentukan sumber daya investasi (Inessa et al., 2019). Salah satu lembaga keuangan yang dapat mendukung kegiatan investasi adalah perbankan melalui pemberian dana pinjaman. Perbankan merupakan subsistem keuangan paling dominan di Indonesia.

Perkembangan industri perbankan berdampak pada tingkat pertumbuhan ekonomi. Abusharbeh (2017) menyampaikan hasil riset yang menunjukkan level pertumbuhan output dipengaruhi secara signifikan oleh perbankan melalui skim pemberian kredit. Menjamurnya perbankan saat ini memberikan tanda bahwa kegiatan lembaga keuangan semakin baik dan berkompetisi dalam menentukan penerimaan masing-masing. Salah satu produk yang menjadi andalan setiap perbankan adalah memberikan kredit kepada masyarakat dalam jangka waktu tertentu. Jika pertumbuhan kredit meningkat, maka menjelaskan kondisi likuiditas perbankan yang semakin baik. Namun jika pertumbuhan kredit menurun, hal ini bermakna likuiditas perbankan buruk. Banyak aspek yang bisa menyebabkan terjadinya penurunan penyaluran kredit perbankan.

Kondisi riil yang dihadapi perbankan setelah proses pemberian kredit disalurkan adalah masalah kredit macet. Besar kecilnya resiko pemberian kredit perbankan dapat dilihat dari ukuran bank tersebut. Mengenai ukuran bank, Margaretha \& Kalista (2018) menyatakan bahwa semakin besar suatu bank dapat menyebabkan semakin tinggi resiko kredit bermasalah. Hal ini ditambahkan pula oleh Alzeaideen (2019) bahwa penting untuk menilai resiko kredit atas perbankan melalui layanan penanganan resiko. Tingginya resiko kredit perbankan berdampak pada kebijakan perbankan untuk pemberian kredit berikutnya dan siklus kegiatan perbankan lainnya. Pada satu sisi, masyarakat membutuhkan pinjaman dari perbankan sebagai modal untuk memulai usaha baru atau meningkatkan produksinya. Namun dalam pengembangan proses kegiatan usahanya, kadangkala tidak berjalan dengan baik seperti yang diharapkan.

Pada sisi yang lain, terdapat hubungan jangka panjang antara indikator makroekonomi dengan stabilitas industri perbankan (Karim et al., 2016). Perbankan dengan sangat selektif memberikan pemberian kredit dan juga mempertimbangkan determinan dari variabel makroekonomi seperti kondisi inflasi yang dapat berpengaruh terhadap suku bunga. Pinjaman dana dari pihak perbankan dapat digunakan sebagai investasi untuk tujuan meningkatkan produktivitas. Gaiotti (2013) menyatakan bahwa ada hubungan antara ketersediaan kredit dengan kegiatan investasi. Hasil risetnya memperlihatkan terdapat elastisitas investasi perusahaan terhadap ketersediaan kredit bank signifikan dalam periode kontraksi ekonomi.

Pemberian kredit pada tipe perbankan konvensional memberi syarat atas adanya penggunaan tingkat suku bunga tertentu. Suku bunga dalam ilmu ekonomi dari teori klasik menyatakan bahwa "bunga" menjelaskan harga kapital (price of capital). Dapat dikatakan jika terjadi peningkatan permintaan uang, maka suku bunga akan meningkat pula. Permintaan uang dilakukan oleh setiap orang untuk tujuan transaksi, investasi, dan spekulasi. Dalam sistem ekonomi kapitalis, salah satu karakteristik untuk permintaan uang pada kegiatan transaksi ekonomi lebih banyak di sektor keuangan dibandingkan dengan sektor riil. Tingkat suku bunga merupakan nilai dari harga sehingga berkaitan dengan inflasi. Teori hubungan antara suku bunga nominal, suku bunga riil, dan inflasi menjelaskan bahwa suku bunga nominal adalah fungsi dari suku bunga riil dan inflasi. 
Teori tersebut tersebut terkenal dengan nama Irving Fisher theory yang menjelaskan bahwa suku bunga dapat mengalami perubahan jika suku bunga riil berubah dan jika inflasi berubah dan teori ini memiliki hubungannya dengan teori kuantitas uang (Dimand, 2000).

Diketahui dari persamaan Fisher bahwa tingkat bunga nominal sebagai jumlah tingkat bunga riil dan inflasi yang diharapkan. Tingkat bunga nominal adalah biaya oportunitas dari memegang uang, yaitu biaya yang timbul karena seseorang lebih suka memegang uang ketimbang obligasi. Semakin tinggi pendapatan (Y), maka semakin besar permintaan terhadap keseimbangan uang riil atau semakin tinggi bunga nominal (i) maka semakin rendah level permintaan terhadap keseimbangan uang riil. Dalam teori Irving Fisher dijelaskan bahwa jumlah uang beredar dan permintaan uang sama-sama menentukan ekuilibrium tingkat harga. Perubahan pada tingkat harga menentukan tingkat inflasi lalu tingkat inflasi mempengaruhi tingkat bunga nominal melalui efek Fisher, yang merupakan biaya dari memegang uang. Tingkat bunga nominal bisa mempengaruhi permintaan uang.

Lebih lanjut dikaji dari sisi teori kuantitas, bahwa jika terjadi kenaikan pertumbuhan permintaan uang sebesar satu persen, maka menyebabkan inflasi meningkat sebesar satu persen. Dari persamaan Fisher dijelaskan pula bahwa kenaikan inflasi akan meningkatkan suku bunga nominal. Analisis teori tersebut menegaskan bahwa suku bunga dan inflasi memiliki hubungan yang positif. Kondisi inflasi dapat berdampak pada hargaharga komoditas yang dibutuhkan oleh masyarakat (Suriani \& Ridzqi, 2019) dan ini dapat mengganggu perekonomian.

Bank Indonesia menggunakan suku bunga kebijakan untuk menjadi instrumen utama dalam upaya mengendalikan inflasi di Indonesia. Suku bunga kebijakan ini memberi dampak pada suku bunga pasar. Dicontohkan dalam hal ini dengan terjadinya kenaikan suku bunga riil, dan biaya pinjaman menjadi mahal. Dengan sendirinya, permintaan uang lalu menjadi menurun. Akibatnya secara agregat, bahwa aktivitas perekonomian lesu. Untuk menggairahkan perekonomian, pihak bank sentral mengeluarkan kebijakan melalui transmisi kebijakan untuk menurunkan suku bunga. Jika suku bunga riil turun, maka biaya pinjaman menjadi murah sehingga permintaan uang meningkat. Pihak investor yang melihat kondisi ini akan memanfaatkan peluang bisnis untuk meningkatkan pangsa pasar, sehingga aktivitas perekonomian menjadi aktif dan dapat meningkatkan kembali output nasional.

Kebijakan suku bunga atas pertumbuhan ekonomi memiliki arah hubungan negatif. Kebijakan bank sentral dengan menaikkan suku bunga dapat menyebabkan pertumbuhan ekonomi menurun dikarenakan pihak investor mengurangi permintaan kredit. Sebaliknya, saat suku bunga diturunkan menyebabkan pertumbuhan ekonomi meningkat karena pihak investor akan meningkatkan permintaan kredit untuk melakukan ekspansi bisnis. Gambar 1 dapat menjelaskan fluktuasi dari hubungan negatif antara kebijakan suku bunga dan level pertumbuhan ekonomi.

Perubahan yang diperlihatkan oleh suku bunga di tahun 2005 sebesar 9,8 persen meningkat menjadi 11,87 persen pada tahun 2006, namun terjadi penurunan pada level pertumbuhan ekonomi menjadi 5,5 persen. Suku bunga tahun 2007 menurun menjadi 8,6 persen, namun pertumbuhan ekonomi bisa meningkat menjadi 6,3 persen. Pada tahun 2012 sampai 2013 terjadi fluktuasi kembali pada suku bunga yang meningkat dari 5,75 persen menjadi 7 persen; dan berakibat pada penurunan pertumbuhan ekonomi dari 6, 17 persen menjadi 5,78 persen. Fluktuasi suku bunga ini bisa berdampak pada aktivitas penyaluran kredit perbankan pada periode tersebut (2012-2013). 


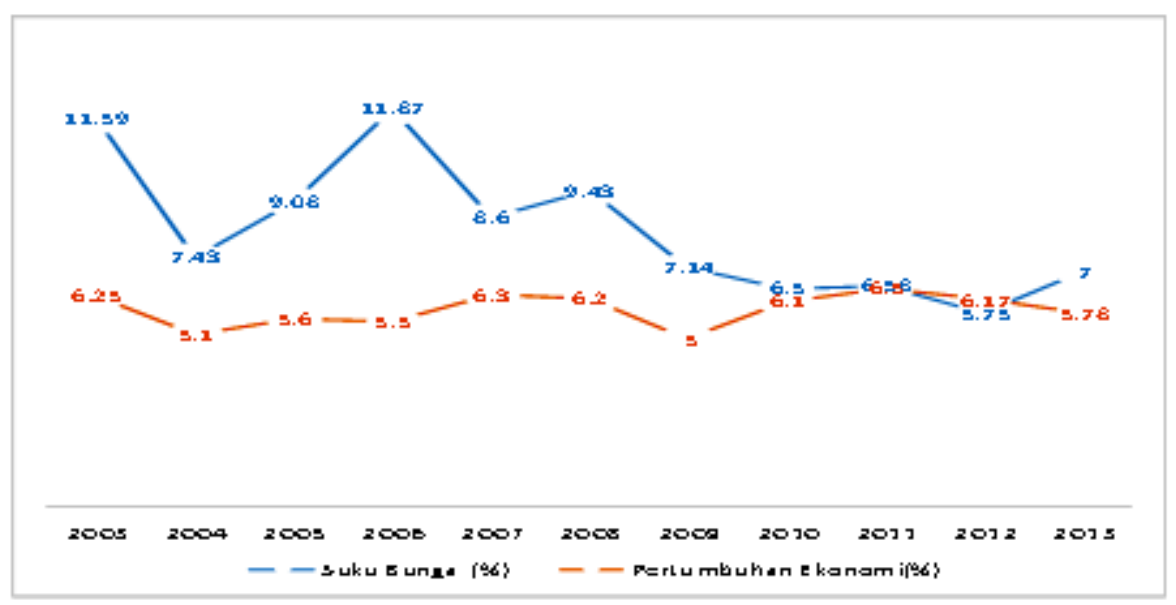

Gambar 1. Suku Bunga dan Pertumbuhan Ekonomi di Indonesia

Sumber: Bank Indonesia., 2014.

Dari hasil laporan Bank Indonesia (2012), perkembangan aktivitas perbankan Aceh, jumlah kredit yang disalurkan oleh Bank umum di Provinsi Aceh cenderung meningkat; namun sedikit melambat di perkuartalan dan diikuti oleh peningkatan total aset perbankan. Seharusnya dengan memiliki peningkatan total aset, maka penyaluran kredit akan meningkat. Namun tidak seperti yang diharapkan oleh perbankan, LDR menurun di setiap kuartalan (Bank Indonesia, 2012). Hal ini berimplikasi terjadi masalah kredit macet seperti dijelaskan Septiani \& Lestari (2016) dari hasil risetnya bahwa NPL (non performing loan) berpengaruh negatif terhadap LDR.

Berdasarkan latar belakang masalah dan penggunaan variabel endogen di dalam penelitian ini adalah model simultan dengan pendekatan two stage least square (2SLS) yaitu PDRB proxy dari perekonomian daerah dan total jumlah kredit, sedangkan variabel yang ditetapkan dahulu (predetermined) adalah suku bunga (r), LDR (loan to deposit ratio), NPL (non performing loan), dan LTV (loan to value). Dengan demikian, terdapat beberapa tujuan penelitian dalam riset ini, yaitu: (1) menganalisis pengaruh perekonomian daerah terhadap permintaan-penawaran kredit di Aceh; (2) menganalisis pengaruh
LDR, NPL, LTV, atas perekonomian daerah di Aceh; dan, (3) menganalisis hubungan kausalitas antara perekonomian daerah dengan total kredit yang disalurkan di Aceh.

\section{Pertumbuhan Ekonomi Daerah dan kredit}

Kondisi perekonomian daerah sangat menentukan proses pembangunan yang berkelanjutan. Kesuma dan Suriani (2015) mengungkapkan bahwa untuk meningkatkan pertumbuhan ekonomi maka perlu memperhatikan pembangunan infrastruktur. Teori neo-klasik di dalam model pertumbuhan memperkuat penjelasan ekonomi dengan output homogen tunggal yang diproduksi oleh dua jenis input, yaitu tenaga kerja dan modal (Samuelson \& Nordhaus, 2010). Unsur-unsur baru dari model pertumbuhan neo-klasik adalah modal dan perubahan teknologi. Untuk meningkatkan pembangunan maka diperlukan modal dan perbankan sebagai satu lembaga keuangan yang dapat menyalurkan dana bagi masyarakat untuk meningkatkan produksi.

Pertumbuhan ekonomi di suatu wilayah atau negara dapat diukur dari besar PDRB atau PDB sebagai pendekatan pendapatan daerah dan atau pendapaatan nasional. Kondisi perekonomian dari daerah sangat menentukan bagaimana keberlanjutan proses pembangunan di suatu wilayah. Hal ini bisa 
ditinjau dari sisi ekonomi, politik, budaya, dan keamanan. Dari beberapa kajian ini maka dapat dimunculkan hipotesis pertama berikut:

H1: Pertumbuhan ekonomi daerah memiliki pengaruh positif terhadap permintaanpenawaran kredit.

\section{Permintaan Uang terhadap Pendapatan (PDRB)}

Permintaan uang adalah keseluruhan uang yang diminta oleh sebuah negara pada periode tertentu (Rahardja \& Manurung, 2005). Ada beberapa hal yang mempengaruhi permintaan uang secara umum. Pertama adalah pendapatan riil yang menjelaskan jika semakin tinggi pendapatan, maka semakin tinggi permintaan akan uang. Hal ini disebabkan karena meningkatnya konsumsi dan jumlah tabungan seiring meningkatnya pendapatan. Kedua yaitu tingkat suku bunga, dimana semakin tinggi suku bunga, maka permintaan uang untuk motif spekulasi akan berkurang karena ketika tingkat suku bunga mengalami peningkatan menyebabkan biaya pinjaman uang untuk berspekulasi akan bertambah mahal. Selain itu, jika suku bunga meningkat, maka masyarakat lebih memilih untuk menabung karena dinilai merupakan pilihan yang lebih menguntungkan dan masyarakat akan memperoleh pendapatan dari suku bunga tersebut daripada berspekulasi.

Ketiga adalah tingkat harga umum, dimana jika semakin tinggi tingkat harga umum, maka semakin tinggi permintaan terhadap uang. Hal ini disebabkan karena harga barang/ jasa semakin mahal sehingga masyarakat membutuhkan uang yang lebih banyak untuk membeli barang. Keempat yaitu pengeluaran konsumen, dimana jika pengeluaran konsumen akan meningkat ketika adanya hari-hari besar seperti Hari Raya Idul Fitri, Puasa, Natal dan hari besar lainnya, yang menyebabkan masyarakat memerlukan uang lebih banyak sehingga permintaan atas uang akan meningkat.

Irving Fisher pertama kali merumuskan persamaan pertukaran dalam bentuk nilai nominal dari transaksi dalam perekonomian yaitu $M V=P T$; dimana $P$ disebut sebagai ratarata harga per transaksi, $T$ adalah jumlah transaksi yang dilakukan dalam satu tahun, serta $V T$ yaitu $P T / M$ adalah percepatan transaksi dari uang. Karena nilai nominal transaksi $(T)$ sulit untuk diukur, sehingga teori kuantitas dirumuskan kembali dalam bentuk output agregat $(Y)$ dimana $T$ diasumsikan proporsional terhadap $Y$ sehingga $T$ sama dengan $v Y$ dimana $v$ merupakan konstanta proporsionalitas. Dengan mensubstitusikan $V Y$ dengan $T$ dalam persamaan pertukaran, Fisher menghasilkan $M V T-V P Y$ dimana $V=$ $V T / V$.

Menurut teori Keynes yang dirujuk oleh Rahardja \& Manurung (2005), ada tiga motif masyarakat ingin memegang uang, yaitu untuk transaksi (transaction motive), berjagajaga (precautionary motive) dan memperoleh keuntungan (speculative motive). Motif transaksi dijelaskan sebagai permintaan uang untuk transaksi dalam teori Keynes adalah sama dengan permintaan uang dalam teori klasik. Dalam pendekatan klasik, alasan seseorang memegang uang dikarenakan uang sebagai alat pertukaran untuk melakukan transaksi sehari-hari; ataupun, transaksi proporsional terhadap pendapatan. Karenanya dimunculkan hipotesis kedua berdasarkan konsep ini, yaitu:

H2: Permintaan uang untuk melakukan kegiatan transaksi pada aktivitas ekonomi berhubungan positif dengan pendapatan (PDRB).

\section{Bunga Kebijakan terhadap Penyaluran Kredit}

Keynes melampaui analisis klasik dengan menyadari bahwa ada tambahan selain 
memegang uang untuk transaksi, dimana seseorang juga memegang uang untuk antisipasi terhadap keperluan yang tidak terduga seperti sakit dan hal tak terduga lainnya. Keynes meyakini bahwa seseorang yang memegang uang untuk berjaga-jaga dalam jumlah tertentu, terutama ditentukan oleh tingkat transaksi yang akan mereka lakukan pada waktu mendatang. Oleh karena itu, Keynes merumuskan permintaan uang untuk berjaga-jaga proporsional terhadap pendapatan.

Konsekuensi dari fungsinya sebagai penyimpan nilai (store of value) adalah uang dapat digunakan sebagai alat mendapatkan keuntungan. Jika Keynes mengakhiri teorinya dengan hanya melihat uang dipegang hanya untuk transaksi dan berjaga-jaga yang mengatakan pendapatan merupakan faktor penentunya, maka hal ini bisa dikatakan sama dengan pendapat klasik. Akan tetapi, Keynes melihat pada sisi lain, yaitu pada sisi di mana seseorang memegang uang sebagai alat penyimpan kekayaan. Memegang uang sebagai alat penyimpan kekayaan inilah yang ia sebut dengan motif spekulasi. Sama halnya dengan motif transaksi dan berjaga-jaga, motif spekulasi juga lebih mengandalkan pendapatan sebagai faktor penentunya. Akan tetapi, Keynes mengkajinya lebih cermat, sehingga menurutnya bahwa selain dari pendapatan, suku bunga juga termasuk ke dalam faktor penentu seseorang memegang uang untuk spekulasi.

Namun demikian, Leiwakabessy (2019) menjelaskan melalui hasil risetnya bahwa suku bunga BPR berpengaruh negatif dan signifikan terhadap penyaluran kredit. Hal ini seirama dengan penelitian yang dilakukan Handayani (2018) dan Indrawati (2017) yang menyatakan bahwa suku bunga kebijakan juga memiliki pengaruh yang negatif terhadap pemberian kredit. Dampak dari adanya peningkatan suku bunga kebijakan adalah terjadinya penurunan penawaran kredit ke perbankan. Bank sentral menggunakan suku bunga kebijakan sebagai salah satu cara untuk mengendalikan inflasi. Berdasarkan penelitian tersebut dijelaskan teori bahwa terdapat hubungan antara suku bunga terhadap kredit (dalam hal ini, perbankan yang melakukan pinjaman kepada bank sentral). Dari hasil kajian ini, maka dimunculkan hipotesis ketiga dalam penelitian ini bahwa:

H3: Suku bunga kebijakan berpengaruh negatif terhadap penyaluran kredit.

\section{Kredit Macet, Rasio Deposit Pinjaman, Nilai Pinjaman terhadap Penyaluran Kredit}

Dalam kehidupan perekonomian yang modern, lembaga perbankan memegang peran penting sebagai intermediasi bagi masyarakat yang memiliki dana dan memberikan kepada masyarakat yang membutuhkan dana. Semakin banyak perbankan yang bersifat likuid dalam pemberian kredit ataupun penyaluran kredit maka perbankan tersebut dikatagorikan ke dalam perbankan yang sehat. Siklus perputaran uang dalam perekonomian juga tergantung dari sistem perbankan. Biondi (2018) menegaskan bahwa kapasitas atau hak istimewa bank yang melibatkan perolehan uang memungkinkan proses penawaran kredit bank. Semua bank menjadi saling bergantung pada aliran pembayaran yang dilakukan di seluruh bank (sistem perbankan). Masingmasing bank secara struktural tidak seimbang karena menghasilkan uang, karenanya koordinasi antar bank diperlukan untuk memelihara sistem perbankan agar dapat beroperasi dari waktu ke waktu.

Beberapa peneliti sebelumnya seperti Siagian (2020) dan Saputro et al. (2019) meneliti tentang faktor yang berpengaruh terhadap kredit bermasalah atau Non Performing Loans (NPL). Dijelaskan pula oleh Qudraty \& Suriani (2016) bahwa Loan to 
Deposit Ratio (LDR) berpengaruh signifikan terhadap NPL. Hal ini dikarenakan tingginya rasio LDR atau rasio deposit pinjaman dapat menyebabkan likuiditas penyaluran kredit menjadi tinggi dengan potensi risiko kredit macet yang juga semakin membesar. Untuk mengurangi level kredit bermasalah, maka perbankan memperhatikan nilai akhir dengan loan to value (Pertiwi \& Arifianto, 2014). Demikian pula penelitian oleh Pratama (2010) menjelaskan bahwa NPL berpengaruh negatif terhadap pemberian kredit.

NPL karenanya menjadi permasalahan yang serius bagi perbankan, sehingga untuk meminimalisasi resiko kredit perbankan, maka perbankan harus memperhitungkan biaya agar terlepas dari resiko pinjaman macet (Louhichi \& Boujelbene, 2020). Berdasarkan pemikiran ini, maka dapat dinyatakan beberapa hipotesis berikut:

H4: Kredit macet berpengaruh negatif terhadap penawaran kredit.

H5: Rasio deposit pinjaman berpengaruh positif terhadap penawaran kredit.

H6: Nilai pinjaman berpengaruh positif terhadap penawaran kredit.

\section{METODE PENELITIAN}

Penelitian kuantitatif inferensial ini menggunakan data sekunder bersumber dari hasil survei statistik kredit yang disurvei oleh Statistik Keuangan Provinsi Aceh Bank Indonesia untuk data permintaan-penawaran kredit, $L T V, L D R, N P L$, serta dari sumber Badan Pusat Statistik Provinsi Aceh untuk variabel pertumbuhan ekonomi Provinsi Aceh (PDRB) dan suku bunga kebijakan (Birate). Periode data estimasi model penawaran dan permintaan uang (total kredit yang disalurkan) adalah data kuartalan dari 2011-2014. Saat penelitian ini dilakukan, Qanun Lembaga Keuangan Syariah (LKS) di Provinsi Aceh belum dikeluarkan.
Lingkup penelitian ini khusus untuk mengetahui determinan makroekonomi (suku bunga dan pertumbuhan ekonomi daerah atau PDRB) serta LDR, LTV, NPL terhadap permintaan-penawaran kredit, dan menganalisis hubungan kausalitas pertumbuhan ekonomi daerah dan permintaan-penawaran kredit di Provinsi Aceh.

Permintaan-penawaran kredit adalah total nilai kredit yang disalurkan bank umum konvensional di Aceh untuk periode 20112014 dan dinyatakan dalam juta rupiah. Produk regional domestik bruto (PDRB) didefinisikan sebagai nilai tambah barang dan jasa akhir yang dihasilkan suatu daerah dihitung menggunakan tahun dasar 2000, diambil dari data yang dikeluarkan Badan Pusat Statistik dan dinyatakan dalam bentuk juta Rupiah. Suku bunga adalah besaran tingkat suku bunga kebijakan BI Rate dalam satuan persen. LDR (Loan to Deposit Ratio) adalah rasio kredit terhadap total dana pihak ketiga yang digunakan untuk mengukur dana pihak ketiga yang disalurkan, dinyatakan dalam bentuk kredit dalam persentase. LTV (Loan to Value) adalah rasio antara nilai kredit yang dapat diberikan bank terhadap nilai agunan berupa properti saat pemberian kredit dalam persentase. NPL adalah total kredit bermasalah pada bank umum di Aceh untuk periode tahun 2011 hingga 2014, dinyatakan dengan satuan ukuran persentase.

\section{Metode Analisis Data}

Metode analisis regresi linear berganda dengan model persamaan simultan, yaitu model yang memiliki lebih dari satu persamaan regresi, digunakan karena adanya persamaan satu dengan yang lainnya saling bergantung (Gujarati, 2003). Perbedaan antara persamaan simultan dengan persamaan tunggal yaitu bahwa pada estimasi parameter persamaan simultan tidak dapat dilakukan tanpa mempertimbangkan informasi pada 
persamaan lainnya, sehingga bisa dikatakan model persamaan simultan menjadi sangat kompleks. Namun kelebihannya, model ini dapat menjelaskan hubungan dua arah antar variabelnya. Dalam studi ini, data diregresi dengan menggunakan aplikasi Eviews10.

Model persamaan simultan terdiri dari beberapa persamaan yang saling berhubungan secara simultan. Dalam penelitian ini, variabel yang diamati adalah pertumbuhan ekonomi daerah (PDRB Aceh) dengan permintaan dan penawaran kredit di Aceh, dengan asumsi bahwa permintaan sama dengan penawaran. Pembentukan persamaan simultan diperoleh menggunakan model regresi, yang selanjutnya diuji apakah mengandung hubungan secara simultan dengan menggunakan uji simultan (Hausman test). Jika kedua persamaan itu terbukti memiliki hubungan secara simultan, maka diperoleh model persamaan simultan.

Sebelum menjalankan upaya penaksiran parameter persamaan simultan, lebih dahulu dilakukan identifikasi yang bertujuan untuk melihat apakah taksiran angka dari koefisien persamaan struktural dapat diperoleh dari koefisien reduced-form yang ditaksir. Jika persamaan tersebut berada dalam kondisi just identified, maka penaksiran parameter persamaan simultan salah satunya dapat dilakukan dengan menggunakan metode Two Stage Least Square (TSLS).

$$
\begin{aligned}
& i=r+\pi \\
& r=\pi-i \ldots \ldots \ldots \ldots \ldots \ldots \ldots \ldots \ldots \ldots \ldots \ldots \ldots \ldots \ldots \ldots \ldots \ldots \ldots \ldots \ldots \\
& \left(\frac{M}{P}\right)^{d}=L(i, Y) \rightarrow\left(\frac{M}{P}\right)^{d}=L\left(r+\pi^{e}, Y\right)
\end{aligned}
$$

\section{Model Permintaan Kredit:}

$K_{D_{t}}=f(P D R B, r)$

$K_{D_{t}}=\beta_{0}+\beta_{1} P D R B_{t}-\beta_{2} r_{t}+\varepsilon t$

\section{Model Penawaran Kredit:}

$K_{S_{t}}=f(L D R, L T V, N P L, P D R B)$

$K_{S_{t}}=\gamma_{0}+\gamma_{1} L D R_{t}+\gamma_{2} L T V_{t}-\gamma_{3} N P L_{t}+$ $\gamma_{4} P D R B_{t}+\mu_{t}$
Untuk melakukan proses analisis model simultan dengan pendekatan TSLS harus meliputi tahapan identifikasi model, membuat persamaan reduced form, dan terakhir mengestimasi model dengan kombinasi hasil variabel reduced form, sebagai berikut:

\section{Tahap 1: Identifikasi model}

Formula yang digunakan untuk tahap identifikasi adalah model $K-k=m-1$, dimana $K$ adalah jumlah variabel eksogen dalam keseluruhan model, $k$ adalah variabel eksogen dalam 1 persamaan regresi, $m$ adalah variabel endogen dalam satu persamaan regresi. Pada tahap ini, Kd dan PDRB merupakan variabel endogen.

Jika nilai K-k dibandingkan dengan $\mathrm{m}-1$ nilainya > 1 maka persamaan tersebut over identified; jika = 1 maka exactly identified; dan, jika $<1$ maka under identified. Bila persamaan tersebut under identified maka tidak dapat diestimasi dengan TSLS, tetapi dengan teknik ILS (indirect Least Square).

\section{Hasil identifikasi:}

Persamaan (4): 4-1 > 2-1 = $2>1=$ Over Identified

Persamaan (6) : 4-3 > 2-1 = $1=1=$ Exactly Identified

Hasil ini menyatakan persamaan (4) dan (6) dapat diestimasi dengan 2SLS.

\section{Tahap 2: Membuat persamaan Reduced Form}

a. Reduced Form PDRB

$\beta_{0}+\beta_{1} P D R B_{t}-\beta_{2} r+\varepsilon t=\gamma_{0}+\gamma_{1} L D R_{t}+$ $\gamma_{2} L T V_{t}-\gamma_{3} N P L_{t}+\gamma_{4} P D R B_{t}+\mu_{t} \ldots \ldots \ldots \ldots .(7)$

$\beta_{1} P D R B_{t}-\gamma_{4} P D R B_{t}=\gamma_{0}-\beta_{0}+\gamma_{1} L D R_{t}+\gamma_{2} L T V_{t}-$ $\gamma_{3} N P L_{t}+\beta_{2} r+\mu_{t}-\varepsilon t$

Atau dapat ditulis persamaannya menjadi:

$\operatorname{PDRB}\left(\beta_{1}-\gamma_{4}\right)=\gamma_{0}-\beta_{0}+\gamma_{1} L D R_{t}+$ $\gamma_{2} L T V_{t}-\gamma_{3} N P L_{t}+\beta_{2} r+\mu_{t}-\varepsilon t$ 
Sehingga diperoleh persamaan keseimbangan nilai PDRB berikut:

$$
\begin{aligned}
& P D R B^{*}=\frac{\gamma_{0}-\beta_{0}}{\beta_{1}-\gamma_{4}}+\frac{\gamma_{1} L D R_{t}}{\beta_{1}-\gamma_{4}}+\frac{\gamma_{2} L T V_{t}}{\beta_{1}-\gamma_{4}}-\frac{\gamma_{3} N P L_{t}}{\beta_{1}-\gamma_{4}}+ \\
& \frac{\beta_{2} r}{\beta_{1}-\gamma_{4}}+\frac{\mu_{t}-\varepsilon t}{\beta_{1}-\gamma_{4}} \quad \ldots \ldots \ldots \ldots \ldots \ldots \ldots \ldots . . . \ldots \ldots \ldots \ldots \ldots \ldots
\end{aligned}
$$

Reduced Form untuk PDRB:

$P D R B^{*}=\alpha_{0}+\alpha_{1} L D R_{t}+\alpha_{2} L T V_{t}-\alpha_{3} N P L_{t}+$ $\alpha_{4} r+v_{t}$

dimana:

$$
\begin{array}{ll}
\alpha_{0}=\frac{\gamma_{0}-\beta_{0}}{\beta_{1}-\gamma_{4}} & \alpha_{1}=\frac{\gamma_{1} L D R_{t}}{\beta_{1}-\gamma_{4}} \\
\alpha_{2}=\frac{\gamma_{2} L T V_{t}}{\beta_{1}-\gamma_{4}} & \alpha_{3}=\frac{-\gamma_{3} N P L_{t}}{\widehat{\beta}_{1}-\widehat{\gamma}_{4}} \\
\alpha_{4}=\frac{\beta_{2} r}{\beta_{1}-\gamma_{4}} & v_{t}=\frac{\mu_{t}-\varepsilon t}{\beta_{1}-\gamma_{4}}
\end{array}
$$

\section{b. Reduced Form Kredit (TK)}

Syarat equilibrium tercapai jika:

$$
K_{D_{t}}=K_{S_{t}}
$$

Dengan cara substitusikan persamaan (9) ke dalam persamaan (4) dimana diketahui nilai total kredit (TK) dari $K d=K s=T K$, maka diperoleh reduced form sebagai berikut:

$$
\begin{aligned}
& T K_{t}= \beta_{0}+\beta_{1}\left(\frac{\gamma_{0}-\beta_{0}}{\beta_{1}-\gamma_{4}}+\frac{\gamma_{1} L D R_{t}}{\beta_{1}-\gamma_{4}}+\frac{\gamma_{2} L T V_{t}}{\beta_{1}-\gamma_{4}}-\right. \\
&\left.\frac{\gamma_{3} N P L_{t}}{\beta_{1}-\gamma_{4}}+\frac{\beta_{2} r}{\beta_{1}-\gamma_{4}}+\frac{\mu_{t}-\varepsilon t}{\beta_{1}-\gamma_{4}}\right)-\beta_{2} r \ldots(11) \\
& T K_{t}= \beta_{0}+\left(\frac{\beta_{1} \gamma_{0}-\beta_{0}}{\beta_{1}-\gamma_{4}}+\frac{\beta_{1} \gamma_{1} L D R_{t}}{\beta_{1}-\gamma_{4}}+\frac{\beta_{1} \gamma_{2} L T V_{t}}{\beta_{1}-\gamma_{4}}-\right. \\
&\left.\frac{\beta_{1} \gamma_{3} N P L_{t}}{\beta_{1}-\gamma_{4}}+\frac{\beta_{1} \beta_{2} r}{\beta_{1}-\gamma_{4}}+\frac{\beta_{1} \mu_{t}-\varepsilon t}{\beta_{1}-\gamma_{4}}\right)-\beta_{2} r \ldots
\end{aligned}
$$

atau,

$$
\begin{aligned}
T K_{t}= & \frac{\beta_{1} \gamma_{0}-\beta_{0}}{\beta_{1}-\gamma_{4}}+\frac{\beta_{1} \gamma_{1} L D R_{t}}{\beta_{1}-\gamma_{4}}+\frac{\beta_{1} \gamma_{2} L T V_{t}}{\beta_{1}-\gamma_{4}}- \\
& \frac{\beta_{1} \gamma_{3} N P L_{t}}{\beta_{1}-\gamma_{4}}+\frac{\beta_{1} \beta_{2} r}{\beta_{1}-\gamma_{4}}+\frac{\beta_{1} \mu_{t}-\varepsilon t}{\beta_{1}-\gamma_{4}}
\end{aligned}
$$

Maka diperoleh persamaan Reduce Form untuk nilai keseimbangan TK adalah:

$$
T K=\alpha_{5}+\alpha_{6} L D R_{t}+\alpha_{7} L T V_{t}-\alpha_{8} N P L_{t}+
$$$$
\alpha_{9}+w_{t}
$$

dimana,

$$
\begin{array}{ll}
\alpha_{5}=\frac{\beta_{1} \gamma_{0}-\beta_{0}}{\beta_{1}-\gamma_{4}} & \alpha_{6}=\frac{\beta_{1} \gamma_{1} L D R_{t}}{\beta_{1}-\gamma_{4}} \\
\alpha_{7}=\frac{\beta_{1} \gamma_{2} L T V_{t}}{\beta_{1}-\gamma_{4}} & \alpha_{8}=\frac{-\beta_{1} \gamma_{3} N P L_{t}}{\widehat{\beta}_{1}-\widehat{\gamma}_{4}} \\
\alpha_{9}=\frac{\beta_{1} \beta_{2} r}{\beta_{1}-\gamma_{4}} & w_{t}=\frac{\beta_{1} \mu_{t}-\varepsilon t}{\beta_{1}-\gamma_{4}}
\end{array}
$$

Setelah disusun reduced form dari TK dan PDRB maka kedua hasil tersebut adalah sama untuk variabel independennya yaitu LDR, LTV, NPL, dan r. Untuk ditampilkan dalam model regresi nanti adalah reduced form dari variabel PDRB.

c. Kausalitas PDRB dan Kredit

Untuk menelaah hubungan kausalitas antara PDRB dengan total kredit (TK) yang disalurkan di Aceh, maka nilai PDRB dicari terlebih dahulu sehingga memperoleh nilai PDRB hat (nilai prediksinya atau predicted value) dari reduce form pada persamaan (10). Selanjutnya, dimasukkan ke dalam persamaan (4), sehingga menjadi persamaan baru sebagai berikut:

$P \widehat{D R B}_{t}=\hat{\alpha}_{0}+\hat{\alpha}_{1} L D R_{t}+\hat{\alpha}_{2} L T V_{t}-\hat{\alpha}_{3} N P L_{t}+$ $\hat{\alpha}_{4} r+v t \ldots(14)$

dimana:

$\mathrm{PDRB}=\widehat{P D R B}+v t$

Sehingga diperoleh nilai TK dalam persamaan untuk model 2SLS.

$K d=\beta_{0}+\beta_{1} \widehat{P D R} B+\beta_{1} v t-\beta_{2} r+$

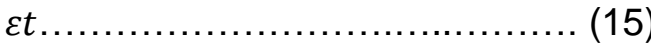

\section{Tahap 3: Membandingkan Hasil Estimasi 2SLS dengan OLS.}

Pada tahap ini akan dibandingkan hasil regresi dalam metode TSLS dengan OLS untuk melihat apakah terdapat perbedaan hasil atau dapat menjelaskan model mana yang lebih baik untuk dapat menjelaskan semua variabel di dalam model penelitian ini. 
Selanjutnya, untuk mengetahui keakuratan data maka perlu dilakukan beberapa upaya pengujian, yaitu uji t-statistik dan uji Fstatistik (Gujarati, 2003).

Uji t-statistik diperlukan untuk menguji parameter hasil estimasi (unrestricted) atas suatu nilai tertentu (restricted) yang menggunakan dua arah t-statistik, menampilkan hasil pengujian estimasi terhadap nilai nol sebagai nilai restriksi yang memiliki arti dua variabel tidak memiliki pengaruh (Ekananda, 2015). Ide dasar test of significance adalah pengujian atas statistik uji (estimator) untuk membuat keputusan untuk menerima atau menolak Ho (Gujarati, 2003). Berikutnya, uji F-statistik dilakukan untuk menguji pengaruh dari variabel-variabel independen secara simultan terhadap variabel dependen, dan koefisien determinasi atau $r^{2}$ menjelaskan besaran total variasi variabel dependen yang dijelaskan model (Gujarati, 2003).

\section{HASIL ANALISIS}

\section{Hasil Uji 2SLS dengan 2 Tahap Regresi.}

Tahap 1: Regresi Persamaan Reduced Form

Persamaan reduced form yang dipakai untuk mengestimasi TK adalah persamaan reduced form PDRB dari persamaan (10). Perolehan hasil estimasi yang dirangkum dalam Tabel 1 dapat ditulis dalam persamaan:

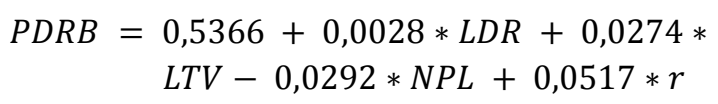

\section{Tahap 2: Regresi persamaan TK dengan menggunakan PDRBhat dan $V_{t}$}

Perhitungan regresi ini menggunakan Persamaan 15, dimana koefisien PDRBhat dan $\mathrm{Vt}$ adalah sama yaitu $\beta_{1}$. Jika nilai $\mathrm{t}$ statistik pada $\mathrm{Vt}$ adalah signifikan, berarti menegaskan terdapat hubungan yang simultan antara total kredit (TK) dan perekonomian daerah (PDRB). Perolehan hasil estimasi yang dirangkum dalam Tabel 2 dapat ditulis dalam persamaan:

$$
\begin{aligned}
T K= & 6,4362+0.7709 * \text { PDRBhat }+0.6856 * \\
& V t-0.0001 * r
\end{aligned}
$$

Berdasarkan hasil uji secara parsial pada Tabel 2 terlihat bahwa variabel PDRBhat berpengaruh positif dan signifikan pada nilai alpha sebesar 1 persen. Nilai koefisien PDRBPhat sebesar 0,7709, artinya jika diasumsikan PDRB meningkat sebesar 100 juta per kuartal maka jumlah kredit yang dapat disalurkan diperkirakan mencapai besaran Rp. 77.090.000 per kuartal. Berdasarkan nilai Adjusted $R$-square yaitu 0,9786 diartikan bahwa tingkat variasi variabel independen memiliki pengaruh terhadap variasi variabel dependen sebesar 98,29\%; sedangkan sisanya sebesar $1,7 \%$ dipengaruhi faktor-faktor lain diluar persamaan regresi ini.

Tabel 1. Reduced Form untuk PDRB

\begin{tabular}{lcccc}
\hline \multicolumn{1}{c}{ Variabel } & Koefisien & Se & t-Stat & Prob. \\
\hline C & 0,5366 & 0,3893 & 1,3784 & 0,1955 \\
LDR & 0,0028 & 0,0036 & 0,7685 & 0,4584 \\
NPL & $-0,0292$ & 0,0206 & $-1,4171$ & 0,1841 \\
LTV & 0,0274 & 0,0138 & 1,9855 & $0,0726^{*}$ \\
r & 0,0518 & 0,0175 & 2,9600 & $0,0130^{* * *}$ \\
R-squared & 0,6568 & & & \\
Adjusted R-squared & 0,5320 & & & \\
\hline
\end{tabular}

Ket: ***level signifikansi 1 persen, **level signifikansi 5 persen, *level signifikansi 10 persen.

Sumber: Data sekunder diolah, 2021. 
Tabel 2. Nilai PDRBhat dan Vt

\begin{tabular}{cc}
\hline PDRB hat & $\mathrm{Vt}$ \\
\hline 1.025205 & 0.013359 \\
1.121807 & -0.06817 \\
1.187891 & -0.11853 \\
1.096855 & -0.01163 \\
1.13268 & -0.03076 \\
1.118552 & -0.00046 \\
1.098693 & 0.034994 \\
1.134419 & 0.014755 \\
1.136126 & 0.029111 \\
1.147418 & 0.033545 \\
1.168831 & 0.027518 \\
1.23955 & -0.028 \\
1.209169 & 0.016511 \\
\hline
\end{tabular}

Sumber: Data sekunder diolah, 2021.

Berikutnya, untuk melihat bagaimana hubungan kausalitas atau sebab akibat antara variabel PDRB dengan total kredit (K), maka dapat diidentifikasi dari nilai $V t$ (variabel residual) yang di regresi dan di uji nilai tstatistiknya. Jika nilai koefisien berdasarkan uji t-statistik adalah signifikan, maka terdapat hubungan kausalitas antara PDRB dan TK.
Berdasarkan hasil dalam Tabel 3 diperoleh terdapat hubungan kausalitas (simultan) antara PDRB dan TK, terlihat dari derajat signifikansi nilai $\mathrm{Vt}$ berdasarkan t-statistik pada $\alpha$ sebesar 1 persen.

\section{Tahap 3:- Membandingkan Hasil Estimasi TSLS dengan OLS}

Hasil estimasi yang sudah diperoleh dengan metode TSLS selanjutnya dibandingkan dengan hasil estimasi menggunakan metode OLS. Tujuannya untuk melihat hasil mana yang lebih baik. Caranya dengan meregresi persamaan awal untuk permintaanpenawaran kredit atau TK pada Persamaan 4. Dipilih persamaan ini karena model untuk Persamaan (4) terindikasi over identified. Untuk menguatkan hasil estimasi untuk kedua metode (OLS dan TSLS), maka diidentifikasi melalui hasil uji asumsi klasik pada Tabel 4. Hasil uji menjelaskan hampir secara keseluruhan tidak terjadi pelanggaran asumsi klasik, hanya terdapat autokorelasi pada model TSLS.

\section{Tabel 3. Hasil Estimasi dengan TSLS}

\begin{tabular}{lcccc}
\hline \multicolumn{1}{c}{ Variabel } & Koefisien & $\mathrm{Se}$ & $\mathrm{t}-$ Stat & Prob. \\
\hline $\mathrm{C}$ & 6.4362 & 0.0459 & 139.9842 & 0.0000 \\
PDRBhat & 0.7709 & 0.0533 & 14.4619 & 0.0000 \\
VT & 0.6856 & 0.0439 & 15.5986 & 0.0000 \\
$\mathrm{r}$ & -0.0001 & 0.0040 & -0.0378 & 0.9705 \\
R-squared & 0.9829 & & & \\
Adjusted R-squared & 0.9786 & & & \\
Durbin-watson stat & 0.8692 & & & \\
\hline
\end{tabular}

Sumber: Data sekunder diolah, 2021.

Tabel 4. Hasil Uji Asumsi Klasik

\begin{tabular}{lllcc}
\hline & \multicolumn{1}{c}{ Uji Asumsi Klasik } & & OLS & TSLS \\
\hline Normalitas & Histogram & Jarque -Bera & 0,58 & 0,28 \\
Multikolinearitas & Correlation & Tidak melebihi 0.9 & 0,56 & 0,73 \\
Heteroskedastistas & Heteroskedasticity Test: Breusch-Pagan-Godfrey & Obs*R-squared & 0,66 & 0,61 \\
Autokorelasi & Breusch-Godfrey Serial Correlation LM Test & Obs*R-squared & 0,11 & 0,04 \\
\hline
\end{tabular}

Sumber: Data sekunder diolah, 2021. 
Tabel 5. Hasil Estimasi dengan OLS

\begin{tabular}{lcccc}
\hline \multicolumn{1}{c}{ Variabel } & Koefisien & Se & t-Stat & Prob. \\
\hline $\mathrm{C}$ & 6,4765 & 0,0330 & 195,7673 & $0,0000^{* * *}$ \\
PDRBhat & 0,7201 & 0,0346 & 20,8180 & $0,0000^{* * *}$ \\
$\mathrm{r}$ & 0,0026 & 0,0034 & 0,7838 & 0,4472 \\
R-squared & 0,9808 & & & \\
Adjusted R-squared & 0,9778 & & & \\
Durbin-watson stat & 0,9581 & & & \\
\hline
\end{tabular}

Ket: ***level signifikansi 1 persen, **level signifikansi 5 persen, *level signifikansi 10 persen.

Sumber: Data sekunder diolah, 2021.

Hasil estimasi pada model Ordinary least square yang ditunjukkan dalam Tabel 5 tidak berbeda dengan penggunaan Two stage least square yang memperlihatkan bahwa pertumbuhan ekonomi berpengaruh positif signifikan terhadap permintaan-penawaran kredit di Provinsi Aceh. Hasil estimasi TSLS paada Tabel 2 diketahui membuktikan adanya hubungan kausalitas antara perekonomian daerah dan permintaan-penawaran kredit.

\section{Pembahasan}

Hasil estimasi dari Tabel 1 (reduced form) memperlihatkan variabel yang mempengaruhi PDRB dari instrumen perbankan adalah LTV (nilai pinjaman) dan suku bunga. Hal ini bermakna bahwa rasio perbandingan pemberian kredit yang disetujui perbankan berpengaruh tehadap perekonomian daerah di Provinsi Aceh. Besarnya nilai pinjaman ini berpengaruh terhadap jumlah uang beredar di Provinsi Aceh. Dari sisi permintaan uang, hal ini membuktikan jika terjadi peningkatan permintaan uang maka aktivitas transaksi dalam perekonomian akan meningkat.

Dari sisi lain, suku bunga di pasar keseimbangan uang riil berdampak langsung pada perbankan dari sisi penawaran jumlah kredit sehingga berpengaruh pada kegiatan transaksi ekonomi yang berdampak pada perekonomian daerah (PDRB). Hasil temuan ini berbeda dengan temuan Handayani (2018) serta teori pada umumnya. Ditegaskan pula oleh Gujarati (2003) bahwa dalam model persamaan simultan, seorang peneliti tidak dapat memperkirakan parameter dari satu persamaan tanpa memperhitungkan informasi yang diberikan dengan persamaan lain dalam sistem. Hasil identifikasi dari pemodelan pada studi ini yang terpilih yaitu over identification yang memiliki makna koefisien persamaan reduced form menghasilkan nilai lebih dari satu pada salah satu koefisien persamaan strukturalnya, sehingga model TSLS adalah pilihan yang tepat.

Selanjutnya, untuk menganalisis pola hubungan kausalitas antara perekonomian daerah dengan permintaan-penawaran kredit, maka dari hasil nilai persamaan reduced form PDRB yang diestimasi dengan OLS dapat diperoleh nilai PDRBhat (perdicted value) dan Vt (calculated residual). Hasil pada Tabel 3 menunjukkan terdapat hubungan kausalitas dua arah antara PDRB dan TK, dibuktikan dengan nilai $\mathrm{t}$-statistik berpengaruh sangat signifikan pada level 1 persen. Temuan hasil riset ini memiliki pengertian total kredit yang disalurkan berdasarkan tingkat permintaanpenawaran kredit di Aceh dipengaruhi oleh perekonomian daerah (PDRB); begitu pula sebaliknya, perekonomian daerah di Aceh dipengaruhi oleh jumlah uang beredar melalui penyaluran kredit atau pembiayaan.

Hasil ini didukung oleh Çepni et al. (2020) yang menjelaskan bahwa pertumbuhan ekonomi sangat sinkron dengan pertumbuhan 
kredit. Thierry et al. (2016) juga menyatakan bahwa kebijakan moneter yang mendukung kredit perbankan pasti akan mendorong perkembangan ekonomi. Demikian pula hasil riset Berger et al. (2021) yang mendokumentasikan efek positif dari integrasi keuangan pada pertumbuhan ekonomi. Hasil-hasil riset para ahli tersebut menunjukkan integrasi keuangan mendemokrasikan pinjaman dan memacu pertumbuhan ekonomi. Hal berbeda dengan hasil temuan penelitian ini adalah pada variabel suku bunga yang ditemukan tidak memengaruhi total kredit (permintaanpenawaran kredit) di Provinsi Aceh untuk periode penelitian 2011-2014.

Hasil uji asumsi klasik pada Tabel 4 menunjukkan estimasi pada model OLS tidak berbeda dengan penggunaan metode TSLS atas variabel PDRB. Temuan menunjukkan PDRB berpengaruh positif terhadap TK (permintaan-penawaran kredit di Provinsi Aceh) secara signifikan pada tingkat $\alpha$ sebesar 1 persen, serta bahwa suku bunga tidak berpengaruh terhadap permintaan-penawaran kredit di Provinsi Aceh untuk periode penelitian 2011-2014. Pada regresi OLS ini belum dapat diketahui apakah antara variabel kredit (TK) memiliki hubungan kausalitas dengan perekonomian daerah (PDRB), karena hasil estimasi pada OLS hanya dapat dilihat pada pengaruh satu arah.

Dari perbandingan hasil regresi dapat disimpulkan TSLS adalah model terbaik dikarenakan parameter koefisien dari setiap variabel bebas dapat dijelaskan sesuai dengan teori dan dapat menjelaskan pengaruh dan hubungan kausalitas. Hasil estimasi TSLS menunjukkan terdapat hubungan kausalitas antara perekonomian daerah dan permintaanpenawaran kredit, yang dibuktikan untuk nilai Vt. Dari hasil regresi menggunakan metode simultan mempertegas terdapat hubungan kausalitas antara pertumbuhan ekonomi daerah dan permintaan-penawaran kredit.
Kondisi perekonomian daerah karenanya dinyatakan dapat berpengaruh positif terhadap permintaan-penawaran kredit. Hal ini berimplikasi bahwa kondisi perekonomian daerah yang kondusif diperlihatkan dari semakin banyaknya aktivitas ekonomi dari sektor perbankan. Hasil studi ini serupa dengan temuan Ramírez-Guerra (2017) yang menjelaskan bahwa pertumbuhan ekonomi memiliki kausalitas dan berpengaruh positif terhadap laju pertumbuhan kredit perbankan.

\section{SIMPULAN}

Temuan hasil penelitian ini menjelaskan pertumbuhan ekonomi daerah berpengaruh positif dan signifikan terhadap permintaanpenawaran kredit di Provinsi Aceh, namun suku bunga terbukti tidak berpengaruh atas permintaan-penawaran kredit tersebut. Hal ini berimplikasi bahwa kondisi perekonomian daerah Aceh yang kondusif dapat meningkatkan total kredit perbankan, sehingga bisa meningkatkan output daerah.

Hasil regresi reduced form pada PDRB memperlihatkan bahwa instrumen perbankan yang berpengaruh terhadap pertumbuhan ekonomi daerah yaitu loan to value (nilai pinjaman) dan variabel suku bunga memiliki hubungan positif. Hal ini berimplikasi bahwa dari sisi penawaran kredit yang diberikan oleh perbankan akan memperhitungkan nilai pinjaman dan suku bunga kebijakan. Jika nilai pinjaman meningkat, maka perbankan akan meningkatkan penawaran kredit. Demikian pula, jika tingkat suku bunga meningkat, maka jumlah penawaran pinjaman meningkat.

Hasil uji kausalitas pada model simultan menunjukkan terdapat hubungan kausalitas antara pertumbuhan ekonomi daerah dan permintaan-penawaran kredit di Provinsi Aceh. Hal ini membuktikan kondisi kondusif perekonomian daerah akan bisa meningkatkan aktivitas perekonomian, dan pihak lembaga keuangan perbankan dapat meningkatkan 
output daerah melalui penyaluran kredit. Oleh karena itu, perlu perhatian pemerintah daerah untuk kebijakan daerah dalam jangka panjang agar kredit lebih diprioritaskan di sektor riil, mengingat permintaan-penawaran kredit memiliki hubungan kausalitas dengan tingkat perekonomian daerah.

Keterbatasan penelitian ini adalah data yang digunakan memiliki periode waktu yang pendek. Kajian yang diteliti juga khusus untuk permintaan dan penawaran terkait dengan total kredit secara umum di perbankan konvensional yang ada di Provinsi Aceh sebelum terbentuk LKS (Lembaga Keuangan Syariah). Penelitian selanjutnya karenanya direkomendasikan untuk meneliti lebih jauh pada sektor perbankan syariah yang sudah menjadi Bank Syariah Indonesia dengan indikator yang berbeda.

\section{REFERENSI}

Abusharbeh, M. T. (2017). The impact of banking sector on economic growth: Empirical analysis from Palestinian economy. International Journal of Economics and Financial Issues, 6(2), 253-258. doi: 10.32479/ijefi.7369.

Alzeaideen, K. (2019). Credit risk management and business intelligence approaches of the banking sector in Jordan. International Journal of Innovation, Creativity and Change, 8 , 218-230. doi: 10.5430/ijfr.v10n6p283.

Bank Indonesia. (2012). Booklet perbankan. Bank Indonesia.

Bank Indonesia. (2014). Statistik ekonomi dan keuangan Indonesia. Retrieved from web.bi.go.id/seki.

Berger, E. A., Butler, A. W., Hu, E., \& Zekhnini, M. (2021). Financial integration and credit democratization: Linking banking deregulation to economic growth. Journal of Financial Intermediation, 45(January), 100857. doi: 10.1016/j.jfi.2020.100857.
Biondi, Y. (2018). Banking, money and credit: A systemic perspective. Accounting, Economics and Law, 8(2), 1-26. doi: 10.1515/ael-2017-0047.

Çepni, O., Hacıhasanoğlu, Y. S., \& Yılmaz, M. H. (2020). Credit decomposition and economic activity in Turkey: A wavelet-based approach. Central Bank Review, 20(3), 109-131. doi: 10.1016/ j.cbrev.2020.06.001.

Dimand, R. W. (2000). Irving Fisher and the quantity theory of money: The last phase. Journal of the History of Economic Thought, 22(3), 329-348. doi: 10.1080/10427710050122549.

Ekananda, M. (2015). Ekonometrika dasar: Untuk penelitian di bidang, sosial dan bisnis. Mitra Wacana Media.

Gaiotti, E. (2013). Credit availability and investment: Lessons from the "great recession." European Economic Review, 59, 212-227. doi: 10.1016/ j.euroecorev.2012.12.007.

Gujarati, D. N. (2003). Basic econometrics $\left(4^{\text {th }} e d\right)$. McGraw-Hill Irwin.

Handayani, A. (2018). Pengaruh DPK, NPL dan ROA terhadap penyaluran kredit pada bank umum yang terdaftar di Bursa Efek Indonesia periode 20112014. Jurnal Akuntansi, 3(1), 623-631. doi: 10.30736/jpensi.v3i1.129.

Indrawati, S. M. (2017). Membangun fondasi untuk pertumbuhan yang berkelanjutan. Kuliah Umum Menteri Keuangan Republik Indonesia di Universitas Syiah Kuala, tanggal 5 Januari 2017.

Inessa, S., Artem, S., \& Wielki, J. (2019). Analysis of macroeconomic factors affecting the investment potential of an enterprise. European Research Studies Journal, 22(4), 140-167. doi: 10.35808/ersj/1503.

Karim, N. A., Al-Habshi, S. M. S. J., \& Abduh, M. (2016). Macroeconomics indicators and bank stability: A case of banking in Indonesia. Buletin Ekonomi Moneter Dan Perbankan, 18(4), 431448. doi: 10.21098/bemp.v18i4.609 
Kesuma, C. N., \& Suriani. (2015). Pengaruh pembangunan infrastruktur dasar terhadap pertumbuhan ekonomi di Indonesia. ECOsains: Jurnal ilmiah ekonomi dan pembangunan, 4(1), 1-18. doi: 10.24036/ecosains.10962757.00.

Leiwakabessy, M. E. (2019). Penyaluran kredit pada bank perkreditan rakyat PT. Modern Express cabang Piru Kabupaten Seram Bagian Barat. Jurnal SOSOQ, 7(1), 59-65. doi: 10.30598/ sosoq.v7i1.987.

Louhichi, A., \& Boujelbene, Y. (2020). Credit risk pricing and the rationality of lending decision-making within dual banking systems: A parametric approach. Economic Systems, 44(1), 100740. doi: 10.1016/j.ecosys.2019. 100740.

Margaretha, F., \& Kalista, V. (2018). Faktor yang mempengaruhi non performing loan pada bank di Indonesia. Jurnal Kesejahteraan Sosial, 3(01), 65-80. doi: 10.31326/jks.v3i01.170.

Pertiwi, D. A. O., \& Arifianto, E. D. (2014). Loss given default (LGD) kredit pemilikan rumah (KPR) di Indonesia: Analisis model industri perbankan dan Bank BTN cabang Purwokerto tahun 2002-2013. Diponegoro Journal of Management, 3(3), 1-15. Retrieved from internal-pdf://135.22.76.238/ 12952-26266-1-SM.pdf.

Pratama, B. A. (2010). Analisis faktor-faktor yang mempengaruhi kebijakan penyaluran kredit perbankan (Studi pada bank umum di Indonesia periode tahun 2005-2009). Jurnal Bisnis Strategi, 19(2), 135-148. doi: 10.14710/jbs.19.2.135-148.

Qudraty, M., \& Suriani, S. (2017). Efektifitas kebijakan makroprudensial perbankan dan penyaluran kredit di Aceh. Jurnal Perspektif Ekonomi Darussalam, 2(1), 32-53. doi: 10.24815/jped.v2i1.6651.

Rahardja, P., \& Manurung, M. (2005). Uang, perbankan, dan ekonomi moneter (Kajian kontekstual Indonesia). FE Universitas Indonesia.
Ramírez-Guerra, E. A. (2017). The economic growth and the banking credit in Mexico: Granger causality and shortterm effects, 2001Q1 - 2016Q4. Economía Informa, 406, 46-58. doi: 10.1016/j.ecin.2017.10.004.

Samuelson, P. A., \& Nordhaus, W. D. (2010). Macroeconomics (Nineteenth ed). McGraw-Hill Irwin.

Sapuro, A. R., Sarumpaet, S., \& Prasetyo, T. J. (2019). Analisa pengaruh pertumbuhan kredit, jenis kredit, tingkat bunga pinjaman bank dan inflasi terhadap kredit bermasalah. Ekspansi: Jurnal Ekonomi, Keuangan, Perbankan Dan Akuntansi, 11(1), 1-11. doi: 10.35313/ekspansi.v11i1.1325.

Septiani, R., \& Lestari, P. V. (2016). Pengaruh NPL dan LDR terhadap profitabilitas dengan CAR sebagai variabel mediasi pada PT. BPR Pasarraya Kuta. E-Jurnal Manajemen Unud, 5(1), 293-324. Retrieved from https://ojs.unud.ac.id/index.php/Manaje men/article/view/15907.

Siagian, S. (2020). Faktor-faktor mempengaruhi non performing loan (NPL) di industri perbankan Indonesia. Jurnal Ecodemica: Jurnal Ekonomi, Manajemen, Dan Bisnis, 4(2), 364-373. doi: 10.31294/jeco.v4i2.8702.

Suriani, \& Ridzqi, F. (2019). Effect of commodity prices on inflation persistence: Partial adjustment approach. Regional Science Inquiry, 11(2). Retrieved from http://www.rsijournal. eu/ARTICLES/June_2019/SI/11.pdf.

Thierry, B., Jun, Z., Eric, D. D., Yannick, G. Z. S., \& Landry, K. Y. S. (2016). Causality relationship between bank credit and economic growth: Evidence from a time series analysis on a vector error correction model in Cameroon. Procedia - Social and Behavioral Sciences, 235(October), 664-671. doi: 10.1016/j.sbspro.2016.11.061. 